\title{
Criminological characteristics of sexual violence
}

\author{
Aldona Kipane \\ Rīga Stradiņš University, Latvia
}

\begin{abstract}
The aim of the current article is to analyse the criminological aspect of sexual violence. Nowadays sexual assault has become a major social issue in many contemporary cultures. Sexual violence is a complex interdisciplinary issue, which includes several aspects psychological, judicial, medical, and other aspects. Sexual crime is an urgent problem with a high level of latency, most part of such crimes are not reported in crime statistics. Particularly, sexual violence against children is a serious problem for Latvia and the world. At present, there is a sharp increase in such crimes as a human trafficking or commercial sexual exploitation; as well as the number of sexual crimes against boys is rising. Expansion of criminal activity in the cyberspace has also increased.
\end{abstract}

Key words: violence, violent crime, sexual violence, sexual crime.

\section{Introduction}

Across the world, crime, disorder and justice are increasingly pressing concern. Fear of crime and proliferating global threats have contributed to a pervasive sense of insecurity $(9,2014)$. Today in criminology describing the crime phenomenon in particular releases of violent crimes. According to Morgan, Maguire and Reiner postmodern criminologists draw on a variety of theoretical perspectives to interpret and explain crime, making it impossible to distinguish clear-cut 'schools' of thought or to identify a specific dominant paradigm (26, 1996).

Criminology defines aggression as an activity resulting in physical harm or mental injury to surrounding people and is accompanied by strong, negative emotions - hate, hostility, and loathing. Mass aggression manifests itself in genocide, terror, ethnic and ideological forms of clashes $(12,2004)$. Violent crime is a major problem worldwide, it manifests itself between individuals, social groups and classes, nations and countries. American researchers' (Friedman, K., Bischoff, H., Davis, R.C. \& Person) state that in recent years crime has become as a metaphor for fear and insecurity. Violence is a complex that rooted in a multitude of discipline, including criminology, psychology, sociology, biology, medicine and other discipline. The research proves that, in Latvia, one of the major threats to the public health and to life is increasing manifestations of violence. Significant amount of violent crimes are committed on the streets, squares, parks or other public places, including schools. Criminal victimization can cause both short-term and long-term stress reaction.

Violence is the intentional use of physical force or power, threatened or real, against another person, or against a group or community that either results in or has high likelihood of resulting in injury, death, psychological harm, mal-development, or deprivation and legally proscribed by law $(28,2011)$. Violence is not only means of reaching one's aims, but also motivational and expressive element - an opportunity to subdue other individuals and to have control over others. Social role theory argued that violence is part of men's nature, not 
women's. According to American social psychologist Leonard Berkowitz, men and women are educated, traditionally, to carry out different social roles. Berkowitz uses the following reasoning for his theory: Think of all the ways in which modern Western society teaches children that fighting is more suitable for men than for women. Folk literature and the media constantly present men, and not women, fighting. Parents buy toy guns for boys and dolls for girls. Parents are more willing to endorse and encourage the aggressive behavior of boys, and not of girls. Again and again, directly and indirectly, minors learn that men are aggressive, and women not $(14,1993)$.

A survey sent to 8000 women and 8000 men found that their partner had victimized approximately $50 \%$ of the women raped by an intimate partner and $66 \%$ of women physically assaulted by an intimate partner multiple times $(16,2003)$. It is further shocking that globally as many as $38 \%$ of murders of women are committed by their intimate partner. Research of the individual health threat origins shows that sexual violence is one of the most serious public health problems with a long-term physical and mental health complications that involve considerable social and public health costs. For example, the number of sexual violence cases affect up to $33 \%$ of women, there are also studies where $53 \%$ of cases of sexual violence where adolescent pregnant women are noted $(1,2008)$. World Health Organization World Report on Violence and Health recognizes that sexual violence results in an increased health risks associated with several body systems, such as, neural, cardiovascular, gastrointestinal, urogenital, reproductive, musculoskeletal, immune and endocrine systems $(37,2002)$. The study of child sex abuse in Latvia highlighted that yearly at least 1000 children suffer from the sexual abuse, although it is presumed that this figure may be considerably higher, up to $5000(22,2007)$. In addition to the negative impact of sexual violence on the physical and mental health, studies reveal that experiencing violence in childhood and adolescence increases the likelihood of experiencing such violence in adulthood $(19,2011)$.

\section{Concept and types of sexual violence}

Nowadays sexual violence has become a social vice and "human weakness" all around the world. Offenses of sexual nature are sexual contacts where one of the partners does not voluntarily agree to it or is involved without realizing the meaning and consequences of the actions thus violating the person's right to sexual self-determination, freedom and sexual inviolability.

Sexual violence is a complicated and complex social and legal problem. Crime victims of sexual violence can have psychological, emotional, and physical trauma. Sexual violence affects people of all genders, ages, races, religions, incomes, abilities, professions, ethnicities, and sexual orientations. Data of sexual violence show that people who sexually assault usually attack someone they know - a friend, classmate, neighbour, co-worker, or relative. For example, the data from the US annual report show that every year, 834700 thousand men are victims of rape and/or physical violence committed by victims' intimate partners (24). According to data of Eurobarometer study on violence against women in Latvia has the highest population tolerance level of violence in the private sphere and a tendency to blame the victim $(5,2010)$. The author's opinion is that sexual domestic violence has an extensive range of problems. Domestic abuse is a specific type of offense, as there is: 1) special relationship (kinship or partnership) between the victim and perpetrator; 2 ) the two share an emotional and often economic dependence; 3 ) domestic violence is rarely a single act, most frequently it is a pattern of behaviour, which over time will continue, and is difficult to stop. It is a cycle of a lasting violent nature, from a few months to several years $(2,2015)$.

The concept of sexual violence is varied. Sexual violence is any sexual act or sexual advance directed at one individual without their consent. According Protection of the Rights 
of the Child Law sexual abuse are the involving of a child in sexual activities that the child does not understand or to which the child cannot knowingly give consent. In a lot of countries the criminal law provides that criminal liability exists for sexual contact with a person who has not reached the age of 16 , even if this person has assented of their own free will to the sexual intercourse and has even wanted it $(4,2003)$.

Sexual violence is related not only to satisfaction of one's sexual needs, but also to the desire for power and control, and to a variety of mental problems. Deviations and problems in sexual life may determine the type of violent forms of behaviour. Perpetrator's behaviour is motivated by both sexual and nonsexual components. Sexual abuse refers to different sexual acts different conditions and forms $(6,2003)$ :

- Rape or sexual assault in order to satisfy sexual proclivity in a marriage or at the beginning of relationship. Date rape which is a violent sexual intercourse during a voluntary social contact. The victim and the offender know each other and spend time together.

- Rape or other sexual activities carried out by a stranger.

- Systematic rape during an armed conflict.

- Sadism - getting sexual enjoyment by causing pain to and/or humiliating the other person. The qualification of such acts depends upon their consequences. Sadistic tendencies lie on the base of many sexual murders, which, however, sometimes have been committed with a view to conceal other sexual crime (rape, seduction to lewdness, etc.) $(3,2003)$.

- Involvement in an unwanted sexual activity (undesirable experience).

- Sexual violence against a mentally ill or a disable person.

- Sexual exploitation. The term "sexual exploitation" means any real or attempted abuse of a position of vulnerability, differential power or trust for sexual purposes, including but not limited to profiting monetarily, socially or politically from the sexual exploitation of another. One aspect of the sexual exploitation of women the objectification of women's bodies through the "male gaze" (the way in which men are encouraged to gaze at a woman's body from male point of view) $(7,2008)$. According to Laura Mulvey the male gaze can be characterised by voyeurism, fetishism and sadism.

- Sexual exploitation of children. Children sexual exploitation is a hidden crime. Young people often trust their abuser and do not understand that they are being abused.

- Forced marriage or cohabitation, including a marriage with a child.

- Other actions (coitus per os or per anum), varyingly arousing a person's body (object insertion in the genitals, anus, mouth, imitating sexual intercourse).

- Prohibiting the use of contraception or other means to protect themselves against unwanted pregnancy and/or sexually transmitted diseases, forced abortion, forced pregnancy, violent sterilization.

- Any act of violence against a person's sexual integrity, including female genital mutilation and compulsory virginity tests.

- Forced prostitution. In Latvia, the average age of women engaged in prostitution is 25-35 years, although age is considered to be a secondary aspect in the provision of sex services. A significant proportion has worked on the streets for a long time (15-20 years). The majority of women in street-based prostitution are addicted to drugs or alcohol, and HIV and other diseases are common amongst women in prostitution with addiction problems: Very often they do not have safe sex [without a condom], because by doing so they can earn more money $(27,2014)$.

- Human trafficking, sexual slavery.

- Distribution of child pornography. 
- Sexual violence is also forcing someone to look at pornographic magazines, movies or to engage in pornographic activities.

- A person is violated with sexual harassment, including undesirable and unpleasant sexual comments. Sexual harassment can take different forms - it can be obvious or indirect, physical or verbal, repeated or one-off and perpetrated by male and females against people of the same or opposite sex (31). Sexual harassment also takes place in case of any kind of unwanted verbal, non-verbal or physical - sexual behaviour, with the purpose and consequence to disregard of other's dignity, in particular when creating and intimidating, hostile, degrading, humiliating or offensive environment. Sexual harassment may include not only physical actions, but also verbal and written, such as sending harassing e-mails or text messages to a mobile phone. The crucial fact is that such and "advertence" is unpleasant.

- Showing one's genitals (Exhibitionism) - denuding of the genitals, often with simultaneous masturbation, within the view of a person of the opposite sex or naked body to other(s) without consent.

- Masturbating in public.

- Watching someone in a private act without their knowledge or permission.

- So-called "honour crimes" (also referred to as, killings in the name of honour, crimes of tradition, or crimes of honour). United Nations FPA estimated that 5000 women are murdered by family members every year in the name of honour $(36,2000)$. According to Human Rights Watch, honour crimes are acts of violence, usually murder, committed by male family members against female family members who are perceived to have brought dishonour upon the family. The misconduct in question may be actual or alleged. A woman may be targeted because she has been raped, has been seen talking to a man outside of the family, has refused to enter an arranged marriage, or even left an abusive husband. Any acts by the victim that may have brought dishonour or shame to the family can trigger attacks on the woman in question $(8,2001)$.

- Cyber-sexual violence: "Cyber-sexual violence is any remote activity of sexual nature and intention in cyberspace violating the rights of another person" $(2,2015)$. For example, cyber-sexual harassment is a fairly widespread phenomenon. The research shows that on average, in EU, cyber-sexual harassment reaches 11\%. Assessing the research results, it can be established that, in Latvia and Estonia cyber-sexual harassment ranges between 10-14\%, compared to Lithuania's 5-9\%.

The author provides a possible definition of sexual violence - sexual violence is diverse, any physical, virtual, or verbal activity or a sexual assault, or an attempt to have sexual contact, or remote actions in cyberspace, or any other activities against the victim's will involving physical force, power, deceit, coercion, or threats or using victim's helplessness or overcoming its resistance thus violating another's sexuality, causing the victim a wide range of concerns: physical pain, mental and physical injury, and material damage.

The author offers a possible concept of sex crime (sexual offense), defining it as an intentional subject's sexual action or actions containing sexual meaning in relation to sociallyaccepted moral norms and values protected by criminal law - real or virtual disregard and violation of victim's sexual freedom and sexual inviolability $(2,2015)$.

\section{Criminal legal aspect of sexual abuse}

According to the Criminal Law of the Republic of Latvia, responsibility for the offences against morality and sexual inviolability is included in the Chapter XVI ("Criminal Offences against Morals, and Sexual Inviolability"). Although interests included the Criminal Law 
Chapter - morality and sexual inviolability are closely related, the theory of criminal law conditionally divide such offenses into two groups: 1) offenses against sexual freedom and sexual inviolability; 2) offenses against morality (35, 2009). They are - Rape (Section 159); Sexual violence (Section 160); Acts of Sexual Nature with a Person who has not Attained the Age of Sixteen Years (Section 161); Leading to Depravity (Section 162); Encouraging to Involve in Sexual Acts (Section 162 ${ }^{1}$ ); Establishment, Maintenance, Management and Financing of Brothel (Section $163^{1}$ ); Involvement of a Person in Prostitution and Use of Prostitution (Section 164); Living on the Avails of Prostitution (Section 165); Sending a Person for Sexual Exploitation (Section $165^{1}$ ); Violation of Provisions Regarding the Demonstration of a Pornographic Performance, Restriction of Entertainment of Intimate Nature and Handling of a Material of Pornographic Nature (Section 166).

These crimes concern the sphere of sexual life a person - both the offender and the victim - that is, the sphere of life that is the most intimate. Most often criminal law provides for criminal liability for several offences that criminal law are usually known by the term sexual crimes. In practice several other criminal offences are also encountered that should be qualified according to other Articles of the Criminal Law, but have at their basis the wish of the subject to satisfy sexual desire $(3,2003)$. The USA criminologist L.J. Siegel indicates that crimes related to sexuality and moral behaviour are frequently considered as crimes against public order or the so-called victimless crime $(15,2006)$ possibly even as sexual theft or other economic crimes. If a person receives sexual satisfaction in a form of fetishism, they may commit a theft or robbery $(20,2000)$. Other forms of sexual crimes include exhibitionism (Section 231 of Criminal Law, hooliganism), a public form of sexual assault (Section 231 of Criminal Law, hooliganism); necrophilia (Section 228 of Criminal Law, desecration of a corpse); bestiality or sodomy ${ }^{1}$ (Section 231 of Criminal Law, cruel treatment of animals). There is separately distinguished the most dangerous sexual offense - sexual murder (intentional killing) if it is related to rape (Section 117. article 7 of Criminal Law). Criminal Law norm includes importance of life and sexual freedom or sexual inviolability, in a certain order, distinguishing primary and secondary interests basing on an offender's perspective $(35,2009)$.

Offenses of sexual nature are sexual contacts where one of the partners does not voluntarily agree to it or is involved without realizing the meaning and consequences of the actions thus violating the person's right to sexual self-determination, freedom and sexual inviolability. This is a serious violation of the fundamental rights, in particular with regard to the rights of a child. The "sexual abuse" means an actual or threatened physical intrusion of a sexual nature, whether by force or under unequal or coercive conditions. Coercion it may be a very different use of force levels - the use of physical force, psychological intimidation, blackmail, threats, or even instances in which a person is unable to give their consent, such as drug, alcohol intoxication, impression, sleep or mental incapacity to assess the situation and personal involvement in prostitution and coercing prostitution.

Analysing the practical materials (criminal processes, judicial practice), the author concludes that, in most cases of sexual offences, it is essential to look at victim's vulnerability and him/her being exploited by the criminal. For example, the analysis of cases carried out by Supreme Court related to Sections 160 and 162 of Criminal Law shows that most of the girls at risk of sexual violence are aged between seven and thirteen years. The number of victims amounted to 176 (144 females, 32 males and 4 people of age) $(34,2007)$.

\footnotetext{
1 (latin Sodomia) Human unnatural sexual desires against animals. Svešvārdu vārdnīca / autoru kolektīvs, Rīga, izdevniecība Avots, 2008, 835. 1pp.
} 


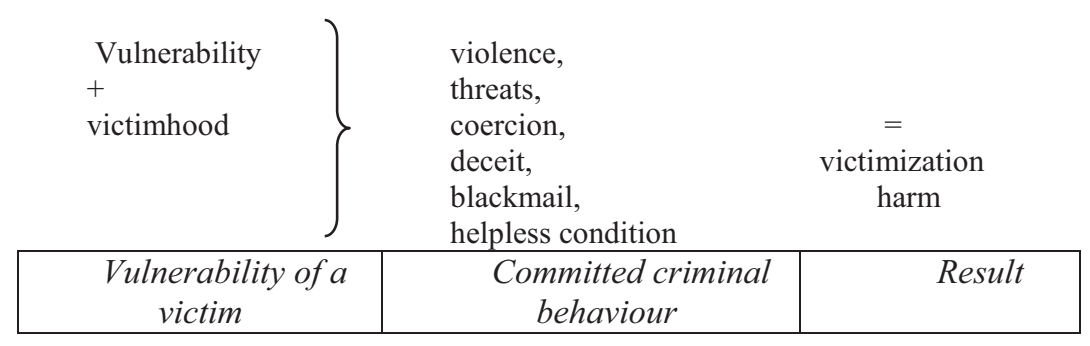

Fig. 1. Diagram, representing the kinds how victim are talked into sexual offenses.

Victims are talked into sexual criminal offenses using a broad spectrum of violence: physical violence, threats, coercion, blackmail, deceit or using the victim's helplessness. The author suggests the following diagrammatic representation of the kinds how victim are talked into sexual offenses $(2,2015)$ :

Criminal statistics only provide an overview of recorded crime. Study of general trends in sexual offences reveals that: the volume of registered sexual offenses is comparatively low, the level recorded annually fluctuates, presenting both recession and growth. In Latvia, statistics show that crimes against morality and sexual inviolability constitute on average approximately $1 \%$ of the criminal offenses.

\section{Sexual crime situation and trends of prevalence}

In Latvia there is no statistics that would disclose the prevalence of violence. Only small part of the committed criminal activities has been recorded in the state available criminal statistics. Criminal statistical indicators are mainly the basis for assessments of the situation of recorded criminality and tendencies. Criminal statistical reports reflect actual criminality, but the situation of criminality should be assessed combined with materials that allow describing this negative phenomenon as a whole (statistical materials, court statistics, sociological and victimization studies and researches). Sexual violence can be depicted as an iceberg. The cases reported to the law enforcement authorities represent only the tip of the iceberg where the cases of sexual violence, which has resulted in the victim's death, are marked. The middle of the pyramid can be found by making different studies and exploring outside the work of law enforcement authorities, but, however, the considerable part of them remain latent (because of the shame, fear, guilt and other factors) which form the bottom of the pyramid. Criminologists estimate that up to $85 \%$ sexual offences remain unknown for law enforcement authorities. The results of different studies concerning the part of registered and latent crimes vary from 1:3, 1:6 to $1: 15$. The intensity of various defamation of a sexual nature differs, for example, "in the case of rape the proportion of recorded and actually committed crimes is in the range of 1:20 and 1:100. That is why there is the disproportion between convicted criminals and number of sexual offences committed" $(22,2007)$.

Victimization studies have acknowledged that victims of sexual offences reported on them in $11.1 \%$ of cases $(21,2002)$. The latest victimization survey showed that over the last five years almost the half of the inhabitants of Latvia has become the victims of sexual offences, $13 \%$ of the respondents became a victim of criminal offence committed by a victim's partner, spouse or other victim's relative $(23,2013)$. The victims' survey confirms that "helplessness, insecurity and weakness are the first emotions that are associated with the victimization experienced. After commitment of a crime each environment, which resembles to a small extent a crime scene, is immediately assessed as threatening and malicious" $(18,2008)$. There should be noted the results of survey which confirm that more than the half of Latvian 
inhabitants $(61 \%)$ consider that educating children about how to protect themselves from sexual violence should be started in the primary school $(30,2011)$.

The results of victimization and sociological studies allow concluding that the victims report about the crime when it was significant or serious for them. It is stated, for example, in the information report that "in case of violence only one third of Latvian women have looked for help of law enforcement authorities. Women have mostly looked for assistance from friends (49.8\%), family members or relatives (41.5\%). Only 3.5\% women contacted the social worker" (11). Reasons for non-reporting on sexual offences are different. The study "Interrogation practice of children suffered from sexual violence in Latvia" acknowledges that in many cases the message has been received after several years after the committing of a criminal offence. There are different reasons why sexual violence against a child remains undetected for several years $(38,2013)$. The author points out that the victims' shame, their fear and unwillingness to be engaged in criminal proceedings and investigation contribute to the latency of sexual offences. It should be stressed that the victim must have the courage to talk about sexual violence experienced. Unfortunately, psychiatric conditions - fear, pain, moral and mental suffering, - which are associated with traumatic memories and which have occurred in the moment of crime or shortly after it, are one of the worst. Fear is the reason not only for emotional and psychological, but also for physiological consequences. "Particular cases acknowledge that even for a long time after the attack or violence a victim still feels intimidated and vulnerable. The study, which was made in Belarus, showed, for example, that in the cases of rape of the minors there was a pressure done by violators or their relatives $-67 \%$; in $62 \%$ of cases the persons changed their testimonies because of pressure" $(10,2008)$. It indicates that the meeting of the needs of the victim is of significance. Postmodern criminology further focuses on the rights and needs of victims - or rather the survivors of crime - in order to restore the harm caused by the criminal act. This is done by means of victim support programmes, restoration and compensation to crime victims, the right to bring to the court's attention the physical, emotional, psychological and economic harm suffered as a result of the crime which should be taken into account for sentencing purposes $(2,1998)$.

The author points out that sexual violence is widely presented both on the personal and group level. It can be divided in several action areas: family, school, army, prison, work, service, street or other public place, for example, in a number of ways and representatives of different groups (divided by race, sexual orientation, social status) have experienced street sexual harassment. For example, people experience calling, being followed, sexual advances grapping or fondling, others exposing themselves, and many ther unwelcome behaviours on the street or public setting (29).

The author concludes that one of the problems of criminological nature of sexual violence is the lack of complete and comparable statistical information. It is difficult to interpret the official statistics because many cases are not reported. It appears that victims of violence often do not report on it because of complex psychological, financial, social and cultural reasons, as well as because of the distrust of police, courts, social assistance and medical services. The author notes that the most of statistical indicators and survey results confirm that violence against one sex is more extent than against the other. Such criminal offences as rape, incest, family violence, marital rape, and acquaintance rape, and forced prostitution, threat of violence, intimidation and torture are included in this group. In addition, it should be noted by the author that the complex issue in the field of research of sexual criminality is a perception of a man as a victim of sexual offence. There is sufficient ground to point to the awareness of female and child victims of sexual violence, but the determination of a male victim has not been properly assessed. The information of men suffered from sexual violence is incomplete. Data of European countries and other world countries provide dispersed information on this 
issue. National Alliance to End Sexual Violence data show that about $14 \%$ of reported rapes involve men or boys and that 1 in 6 reported sexual assaults is against a boy and 1 in 25 reported sexual assaults is against a man. As with male sexual violence against women, sexual violence against men is motivated by the desire to dominate and use sex as a weapon against the victim. Male victims experience similar effects of sexual violence as female victims such as shame, grief, anger and fear. Male victims may also have issues surrounding their sexual and/or gender identity after a sexual assault $(16,2003)$. In accordance with the data provided by Latvian expert Irina Novikova, up to $27 \%$ of men become a victim of violence in intimate relationships. In Iceland - 0.8\% (33, 2011). During the year 1489 men suffered from violence in Latvia, 85 of them experienced the violence in their families (the most men who suffered from domestic violence were men in the age of 30 to 34) (13). Victimization studies acknowledge that generally men experience violence in public places, boys - in the family. It is statistically proved that more young men become victims of violent criminal offences. In addition, due to the delicate nature of the question of sexual violence the collection of data of the number of male and female victims is problematic. It is likely that male representatives will deny the illegal sexual actions and will not witness about sexual violence. Exceptions are especially severe cases, for example, in Valdemarpils during the use of alcoholic beverages with two childhood friends $M$. and $R$., $R$. experienced the sexual violence. In the result of sexual violence intestine of the victim was pierced and that is why the urgent operation was carried out.

Giving an overview about tendencies of sexual violence, it can be pointed, that during the last several years various studies have been carried out and criminal statistics indicate several negative tendencies: the number of children suffering from sexual violence is rather big; the criminal actions have substantially increased in the cyber area, human trafficking with the aim of commercial sexual exploitation is increasing.

The author concludes that there is a lack of strategic, research and scientifically based approach to the research of criminality whose results could affect the formation of criminal policy directions. It is necessary to create an independent body with a sufficient professional capacity. The author believes that under the Ministry of Justice of the Republic of Latvia, an institute for legal and crime research should be established with the following main functions: criminal analysis in order to forecast and develop criminal policy, scientific research, proposal development and the provision of legal, social and organizational measures for the implementation of crime prevention; cooperation with international organizations in the field of crime prevention.

Prevention and combat of sexual offences have become one of the major issues in the work of Latvian law enforcement agencies and international organizations.

\section{Conclusions}

Defamation of sexual nature is difficult and sensitive topic. They cause the most unfavourable consequences and are mostly hidden and ignored. The prevalence of sexually aggressive behaviour in the society is still a priority issue.

In Latvia, the regular inhabitants' victimization monitoring is necessary to use the conclusions gained for prevention process of criminality. In order to improve the victimization prevention measures, it is necessary to make systematic, determined and complex identification of potential victim, as well as right social, legal, physical and sexual education of potential victim is essential.

Measures for sexual crime prevention include a certain degree of difficulty. Firstly, there must be ensured physical inviolability, meaning the prevention of crime in the individual's personal space or surroundings. Secondly, there must be provided a proper impact on the 
individual in order to facilitate his/her proper legal behaviour and the development of socially useful skills, etc. Thirdly, the circumstances and reasons that contribute to the crime must be identified and neutralized.

\section{References}

[1] A. Frye, Holistic Midwifery: A Comprehensive Textbook for Midwives in Homebirth Practice, 1 (Care During Pregnancy, Portland, Oregon, Labrys Press, 2008)

[2] A. Kipāne, Seksuālās vardarbības problēmas: promocijas darbs (Rīga, Rīgas Stradiña universitāte, 2015)

[3] B. Naude, Acta Criminologlca 11(2) (1998)

[4] Crime Investigation (Investigative Features of the most Frequently Encountered Crimes), edited by A. Kavalieris Riga, publishing House "Valters un Rapa" Ltd (2003)

[5] Domestic Violene agaist Women Report (2010). Avaible on: http://ec.europa. eu/public_opinion/archives/ebs/ebs_344_en.pdf

[6] Guidelines for medico-legal care of victims of sexual violence. World Health Organization (2003). Available on: http://whqlibdoc.who.int/publications/ $2004 / 924154628 X \cdot p d f$

[7] G. Letherby, K. Williams, P. Birch, M. Cain, Sex as Crime? (Routledge, Taylor \& Francis Group, New York, 2008)

[8] Human Rights Watch. "Integration of the human rights of women and the gender perspective: Violence Against Women and "Honor" Crimes," 5 April (2001)

[9] J. Muncei, D. Talbot, R. Walters, Crime: Local and Global (Routledge Taylor \&, Francis Group, London and New York, 2014)

[10] I. Poudžiunas, Jurista vārds, 42(547) (2008)

[11] Informatīvais ziņojums par problēmām saistībā ar vardarbību gímenē un to iespējamiem risinājumiem. Available on: http://www.bm.gov.lv/lat/gimenes_ valsts_politika/vardarbiba_gimene/?doc $=9423$

[12] Kriminologija / zin. red. K. Ķipēna, V. Vilks. Rīga, Nordik (2004)

[13] Krīžu un konsultāciju centrs Skalbes. Available on: http://www.skalbes.lv/ aktualit

[14] L. Berkowitz, Aggression: Its causes, consequences, and control (McGraw-Hill, New York, 1993)

[15] L.J. Siegel, Criminology: Theories, Patterns, and Typologies (Cengage Learning, Blemont, 2006)

[16] M.R. Rand, L.E. Saltzman, J. Comp. Fam. Stud. 34 (2003)

[17] Male victims. Available on: http://endsexualviolence.org/where-we-stand/ male-victims

[18] Naida noziegumu psihologiskās sekas - cietušā pieredze un ietekme uz plašāku sabiedrību (Latvijas Cilvēktiesību centrs, 2008)

[19] NISVS. National Intimate Partner and Sexual Violence Survey. Summary Report 2011. Available on: http://www.cdc.gov/violenceprevention/pdf/ nisvs_report2010-a.pdf

[20] Noziegumu izmeklēšanas metodika / prof. A. Kavaliera vadībā, (Rīga, Latvijas Policijas akadēmija, 2000)

[21] Noziedzības stāvoklis Latvijā: noziegumu upuru aptaujas rezultāti (Rīga, Latvijas Kriminoloqgisko pētījumu centrs, 2002)

[22] Pētījums, "Latvijas un citu valstu pieredze darbam ar seksuālajiem noziedzniekiem (kopsavilkums ar pētījuma elementiem par esošo situāciju un tās iespējamajiem 
risinājumiem)" (2007). Available on: http://www.probacija.lv/uploads/ petijumi/vpd_petijums_gala_variants.pdf

[23] Pētījums, "Atbalsts Viktimizācijas prevencijai Latvijā". "Sabiedriskās politikas centrs PROVIDUS", 2013. Available on: http://www.providus.lv/public/ 27837.html

[24] P. Tjaden, N. Thoennes, Prevalence, Incidence, and Consequences of Violence Against Women: Findings From the National Violence Against Women Survey. Available on: https://www.ncjrs.gov/pdffiles/172837.pdf

[25] Pētījums par bērnu seksuālo izmantošanu Latvijā.Available on: www.riskchild. org/.../Atskaite_bernu\%20seksula\%20izmant.\%203.do...

[26] R. Morgan, M. Maguire, R. Reiner, Introduction in the Oxford Handbook of Criminology (Clarendon Press, Oxford, 1996)

[27] Recruitment for Human Trafficking and Online Image of Women: Case Studies of Latvia, Estonia and UK (2014). Available on: http://marta.1v/docs/ 1283/2015/Marta_ENG_print.pdf

[28] S. Mire, C. Roberson, The Study of Violent Crime: Its Correlates and Concerns (Taylor \& Francis Group, LLC, 2011)

[29] Sexual Harassment. Available on: www . humanrights . gov . au

[30] Sliktais pieskāriens, Krīzes centrs ğimenēm ar bērniem Paspārne. 2011. Available on: http://www.kc-pasparne.1v/lv/aktualitates/155_sliktais_pieskariens/

[31] Sexual Harassment, RAINN. Available on: www.rain.org/articles/sexual

[32] Svešvārdu vārdnīca, autoru kolektīvs (Rīga, izdevniecība Avots, 2008)

[33] The Role of Men in Gender Equality - European Strategies \& Insights. Study on the Role of Men in Gender Equality Contract ref. no. VC/2010/0592 December 2012. European Union, 2013, p. 109. Novikova I. (2011). Country report Latvia. Unpublished working paper within the project Study on the Role of Men in Gender Equality

[34] Tiesu prakse krimināllietās pēc Krimināllikuma 160. un 162.panta (Tiesu prakses apkopojums apspriests departamenta senatoru kopsēdē 2007.gada 27.septembrī). Latvijas Republikas Augstākā tiesa. Available on: http://www.at.gov.lv/ lv/info/summary/2007/

[35] U. Krastiņš, V. Liholaja, A. Niedre, Krimināltiesības. Sevišksā daļa (Rīga, Tiesu namu agentūra, 2009)

[36] UNFPA State of World Population 2000. Lives Together Worlds Apart. Available on: http://www .unfpa.org/sites/default/files/pub-pdf/swp2000_eng.pdf

[37] World Report on Violence and Health / edited E.G Krug, Mercy A.J., Zwi B.A. and Rafael Lozano R. Geneva, World Health Organization WHO (2002)

[38] Ziņojums par pētījuma "Seksuālā vardarbībā cietušo bērnu nopratināšanas prakse Latvijā" rezultātiem (2013). Available on: http://www.bernskacietusais.lv/ lv/petijumi/kkk/zinojums-par-petijuma-seksuala-vardarbiba-cietusobernu-nopratinasanas-prakse-latvija-rezultatiem-20-336/ 